Научная статья

УДК 1.14 .140

DOI: $10.17213 / 2075-2067-2021-6-264-274$

\title{
ЗДОРОВЬЕ ЧЕЛОВЕКА КАК ПРЕДМЕТ НАУЧНОГО ДИСКУРСА В ОБЛАСТИ СОЦИАЛЬНО-ГУМАНИТАРНОГО ЗНАНИЯ
}

\author{
Илья Владимирович Чернов
}

\section{Новочеркасский инэенерно-мелиоративный институт имени А. К. Кортунова (филиал), Донской государственный аграрный университет, Новочеркасск, Россия e-mail: ichernov1966@mail.ru}

Аннотация. Цель исследования заключается в анализе теоретических подходов к проблеме здоровья человека, сложившихся в социально-гуманитарном знании.

Методологической основой исследования являются междисииплинарная методология, позволяющяая интегрировать данные различных областей научного знания; холистический подход к пониманию здоровья как системь, включающей биологическую, психологическую и духовную сферы в структуре личности; философско-антропологический подход к пониманию сущчности человека; аксиологический подход, в рамках которого здоровье рассматривается как иеенность, обусловленная специификой культуры соииума.

Результаты исследования. Здоровье человека не является исключительно проблемой медицинского характера, напротив, это проблема онтологическая, открывающая возможность понять существование человека как иелостности, в совокупности его биосочиальной природь и духовной сущности. Философско-антропологический ракурс исследования здоровья человека предполагает интеграцию подходов, сложившихся в социально-гуманитарном знании, что дает возможность осуществить комплексное исследование проблемь здоровья человека в контексте трансформации культурных парадигм и появлении новых вызовов.

Перспективы исследования. Работа открывает перспективы для дальнейшего исследования рисков и угроз здоровью человека в условиях дальнейшей технологизации общества и развития циирровой культуры.

Ключевые слова: здоровье человека, междисииплинарные исследования, психологическое здоровье личности, поведенческие стратегии, здоровье и безопасность, телесность человека, биосочиальная природа человека

Для цитирования: Чернов И.В. Здоровье человека как предмет научного дискурса в области социально-гуманитарного знания// Вестник Южно-Российского государственного технического университета. Серия: Социально-экономические науки. 2021. T. 14, № 6. C. 264-274. http://dx.doi.org/10.17213/2075-2067-2021-6-264-274.

(С) Чернов И.В., 2021 
Original article

\title{
HUMAN HEALTH AS A SUBJECT OF SCIENTIFIC DISCOURSE IN THE FIELD OF SOCIAL AND HUMANITARIAN KNOWLEDGE
}

\author{
Ilya V. Chernov
}

\section{Novocherkassk Reclamation Engineering Institute named after A. K. Kortunov (branch), Donskoy State Agrarian University, Novocherkassk, Russia e-mail: ichernov1966@mail.ru}

\begin{abstract}
The purpose of the study is to analyze the theoretical approaches to the problem of human health, which have developed in social and humanitarian knowledge.

The methodological basis of the research is an interdisciplinary methodology that allows integrating data from various fields of scientific knowledge; a holistic approach to understanding health as a system that includes biological, psychological and spiritual spheres in the structure of the personality; philosophical and anthropological approach to understanding the essence of man; an axiological approach, within which health is viewed as a value determined by the specifics of the culture of society.

Research results. Human health is not exclusively a medical problem; on the contrary, it is an ontological problem that opens up the possibility of understanding the existence of a person as a whole, in the aggregate of his biosocial nature and spiritual essence. The philosophical and anthropological perspective of the study of human health presupposes the integration of approaches that have developed in social and humanitarian knowledge, which makes it possible to carry out a comprehensive study of the problem of human health in the context of the transformation of cultural paradigms and the emergence of new challenges.

Research prospects. The work opens up prospects for further research of risks and threats to human health in the context of further technologization of society and the development of digital culture.

Keywords: human health, interdisciplinary research, psychological health of an individual, behavioral strategies, health and safety, human corporeality, biosocial human nature

For citation: Chernov I.V. Human health as a subject of scientific discourse in the field of social and humanitarian knowledge // Bulletin of the South Russian State Technical University. Series: Socio-economic Sciences. 2021; 14(6): 264-274. (In Russ.). http://dx.doi.org/10.17213/20752067-2021-6-264-274.
\end{abstract}

Введение. Актуализация проблемы здоровья человека в современном научном дискурсе обусловлена влиянием на него различных факторов (экологических, эпидемиологических, социальных и пр.), которые несут в себе серьезные угрозы как для нынешнего, так и будущих поколений. Стремительные и малопредсказуемые в своих последствиях социальные процессы, связанные с технологизацией жизни людей, с ростом стрессовых ситуаций, способствующих развитию патологических состояний и обострению хро- нических заболеваний, повышают интерес социальных наук к проблеме здоровья человека, активизируют исследования в области его сохранения, укрепления и профилактики. Очевидно, что здоровье людей является самым ценным ресурсом для воспроизводства и дальнейшего развития современного общества. Понимание этого заставляет политических лидеров и научное сообщество обращать внимание на этот человеческий потенциал и искать способы улучшения физического, психического и социального здоровья людей. 
Тема здоровья является предметом научного интереса различных областей знания: медицины, философии, психологии, социологии, демографии и экологии. Это свидетельствует о многоаспектности данной проблемы, ее актуальности и значимости, как для науки, так и для жизни человека в целом. В области социально-гуманитарного знания здоровье рассматривается, прежде всего, как социокультурный феномен, обусловленный спецификой общества, уровнем его культурного и технологического развития, который оказывает влияние на физическое, психологическое и духовное состояние человека.

Методология и методы исследования. В статье использована междисциплинарная методология, позволяющая интегрировать методы различных областей научного знания: истории философии, психологии, социологии, философской антропологии, социальной философии и др.

Методологической основой исследования выступает неоклассическая модель, позволяющая применять холистический подход к изучению здоровья человека как системы, включающей биологический, психологический и духовный уровни в структуре личности. Данный аспект исследования представлен в работах В.М. Бехтерева, К. А. Оглоблина, В.М. Розина, Т.Н. Шушуновой и др. $[8 ; 30 ; 37 ; 43]$.

Данное исследование опирается на философско-антропологический подход к пониманию телесности человека, разрабатываемый Р. Бартом, Ж. Батаем, Ж. Бодрийяром, М. Мерло-Понти, М. Фуко и др. [5; 6; 9; 27; 39].

Концептуальными для исследования является аксиологический подход, в рамках которого здоровье рассматривается как ценность, обусловленная культурой общества и его мировоззренческими установками. В этом аспекте здоровье человека исследуется в работах Е.В. Андриенко, Р.А. Пидлубного, С. А. Нижникова, Б. Г. Юдина, Г.Б. Степановой и др. [3; 29; 44].

Данные подходы выступают теоретико-методологической основой исследования проблемы здоровья человека как сложной многоуровневой структуры, состояние которой зависит от социальных факторов.
Здоровье человека как предмет междисциплинарных исследований. В современном научном дискурсе проблема здоровья человека является предметом исследования различных научных областей: медицины, психологии, социологии, экологии, философии.

Медико-социальный подход к пониманию здоровья человека акцентирует внимание на вопросах диагностики, реабилитации, профилактики заболеваний, а также оценки экономических и медицинских ресурсов государства в профилактике заболеваний и сохранении здоровья населения. С точки зрения академика Н. М. Амосова, здоровье организма человека определяется «его количеством, которое можно оценить максимальной производительностью органов при сохранении качественных пределов их функций» [2, с. 72]. В данном определении очевиден акцент на биологическую природу человека, на количественные показатели его физического здоровья.

Психологический подход к здоровью человека развивается в работах западных ученых А. Маслоу, Г. Олпорта, К. Роджерса, которые конструируют свои модели здоровой личности [26; 31;36]. Основатель гуманистической психологии Г. Олпорт связывает здоровье человека со степенью психологической зрелости личности. Для описания специфики человека ученый вводит понятие «проприум», обозначающее позитивное, творческое, развивающееся свойство человеческой природы, которое способствует формированию чувства внутреннего единства, осознанию человеком собственной «самости» [31, c. 218]. Именно понимание человеком своей целостности, цельности и автономности является критерием психологической зрелости личности и основой ее здоровья.

В концепции К. Роджерса психологическое здоровье личности связано с ее способностью к самоактуализации, которая предполагает следование своей «самости» как высшей инстанции психической сферы человека. Следовать своей «самости», по мнению психолога, это значит опираться на свои чувства, доверять им. Действия индивида в соответствии со своими установками и ощущениями К. Роджерс называет «конгруэнтностью», наличие последней и определяет психологический комфорт личности [36]. 
Аналогичной позиции придерживается и А. Маслоу, полагающий, что психологически здоровый человек - это самоактуализирующаяся личность, которая умеет «сонастраиваться со своей внутренней природой» $[25$, с. 57]. По мнению психолога, для обретения состояния психологического равновесия человек должен доверять своей интуиции.

Такой подход базируется на признании необходимости безусловного доверия человека к своей внутренней природе, которая подсказывает ему, как жить, чтобы оставаться самим собой в процессе самоактуализации, что позволит сохранить свое психологическое здоровье. Данные подходы к психологическому здоровью опираются на интерсубъективное понимание внутренней жизни человека, на значимость его собственного опыта во взаимодействии с окружающим миром.

В отечественной научном дискурсе психологический подход к здоровью человека развивается в работах отечественных исследователей В.М. Бехтерева, Т.И. Безуглой, И.В. Дубровиной, О.В. Завгородней, М.М. Решетникова, А. В. Шувалова и др. [8; $7 ; 16 ; 19 ; 35 ; 42]$.

Концептуальным в понимании здоровья человека является теория психологического поведения В.М. Бехтерева, где здоровье человека рассматривается как многоуровневая система, включающая: а) биологический уровень; б) психологический уровень; в) социальный уровень. Именно их взаимосвязь и согласованность определяет состояние здоровья человека. Надо отметить, что В. М. Бехтерев был одним из первых российских ученых, считавших здоровье человека ключевой проблемой современной науки, поэтому обращался к исследованию профилактики психологических заболеваний и воспитанию здорового образа жизни [8].

Следует отметить, что многоуровневый подход к здоровью является наиболее продуктивным, поскольку человек представляет собой сложное существо, в котором действительно совмещаются различные уровни его организации: физический, психический, духовный и социальный. Именно их взаимосвязь определяет целостность личности, и, конечно, сбой в одной из этих сфер влечет за собой разбалансировку всего организма человека. В рамках данного подхода здоровье человека рассматривается как «совокупность характеристик личностности, предполагающих стрессоустойчивость, социальную адаптацию, самореализацию, что подчеркивает индивидуальность человека» [16, с. 57].

Можно согласиться с точкой зрения А.В. Шувалова, подчеркивающего, что для нормализации психологического здоровья важна не только стабилизация социальноэкономической и политической сфер общества, но и условия для духовно-нравственного совершенствования человека. Более того, «чтобы психология могла полноценно включиться в процесс исцеления современного человека и общества, требуется реабилитация духовного начала внутри самой психологии. Сегодня это важный аспект развития научного психологического знания〉 [42, с. 34].

В целом в рамках психологического подхода исследователи под здоровьем понимают один из механизмов функционирования человека в социальной среде. Таким образом, исследователи фиксируют влияние социума на психику людей, роль общественных трансформаций, которые оказывают травматическое воздействие на психическое состояние человека и социальных групп.

Наряду с психологическим подходом, в научном дискурсе развивается и социологический подход к здоровью человека, представленный в работах Н.Л. Антоновой, Т.В. Гутик, Е.В. Дмитриевой, И.С. Паутова, Д. С. Чубенко и др. $[4 ; 12 ; 15 ; 32 ; 41]$.

Следует отметить, что проблематика здоровья относительно недавно вошла в исследовательское поле социологии, но, несмотря на это, на сегодняшний день в социологическом знании сложилась новая отрасль - социология здоровья, где разрабатывается свой понятийный аппарат и методологические подходы.

Социологи акцентируют внимание преимущественно на демографических показателях здоровья; социальных факторах, определяющих здоровье населения; функционировании институтов, деятельность которых направлена на сохранение и развитие здоровья; проблеме здоровья в контексте социального неравенства; поведенческих стратегиях в сфере здоровья и т.д. Исследователи отмечают, что «рассматривая здоровье как социальный феномен, социология концентрирует 
внимание на его социальных детерминантах, его социальной природе, месте в системе социокультурных ценностей, регулирующих поведение человека» [12, с. 215].

Обращая внимание на социальную обусловленность здоровья человека, социологи справедливо указывают на то, что «здоровье - это одновременно проблема и социальная, и биологическая. Как и благосостояние, оно зависит от уровня и распределения ресурсов общества» [41, с. 121]. Таким образом, здоровье рассматривается как биологическая и социальная системы, взаимовлияние которых друг на друга позволяет оценивать комплексное состояние человека и общества.

По мнению Н. Л. Антоновой, «здоровье представляет собой один из интегральных показателей качества жизни, в нем отражаются демографические, социальные процессы общества, уровень социокультурного и экономического развития, качество функционирования системы здравоохранения» [4, c. 113].

Концептуальным для понимания социальной обусловленности здоровья человека является исследование процессов социальной адаптации индивидов и групп к институциональным трансформациям, происходящим в российском обществе. Социологи правомерно указывают на то, что стремительные социальные изменения значительно опережают адаптивные возможности человеческого организма, что влечет за собой значительные физические, психологические и духовные нагрузки. С позиции адаптационного подхода здоровье трактуется как «отражение процессов адаптации индивида к окружающей природной и социальной среде, представленное в виде показателей физического, а также психического и социального благополучия (неблагополучия) этой системы в определенный момент времени» [32, с. 294]. Таким образом, рассогласованность между социальной средой и адаптивными ресурсами личности сопряжена с ростом рисков и угроз здоровью населения транзитивных обществ.

В рамках социологических исследований проблема здоровья анализируется в контексте проблематики человеческого капитала и социальной безопасности как индивида, так и общества в целом. Так, ряд исследователей рассматривает здоровье как капитал в струк- туре человеческого капитала, который оказывает существенное влияние на формирование и самореализацию личности. Здоровье как капитал представляет собой инвестицию в человека, необходимую для его жизнедеятельности и работоспособности. В этом аспекте ученые отмечают, что «здоровье является с одной стороны потребительским благом, на которое предъявляется спрос, а с другой стороны - инвестиционным благом, которое определяется по чистой стоимости выгод, получаемых от данного блага» [17, с. 388].

В последнее время проблема здоровья человека часто рассматривается в контексте вопросов безопасности общества. Данный аспект представлен в работах Н.С. Горяиновой, М. З. Казиевой, Е. Г. Поздеевой, В.В. Евсеева и др. [11;21; 34]. В рамках этого подхода здоровье определяется как норма, «включающая не только физические, биологические, но и общественные, социально-политические и духовно-нравственные аспекты жизнедеятельности молодого человека, и тем самым способствующая формированию условий безопасности общества» $[21$, с. 54]. Очевидно, что в условиях повышения в современном мире рисков различной этимологии, здоровье человека является фактором обеспечения национальной безопасности государства.

В целом социологические исследования в области здоровья обладают значительным эвристическим потенциалом, который позволяет более комплексно изучить социальные факторы, влияющие на состояние здоровья человека. Опираясь на концепцию «общества риска» Э. Гидденса, У. Бека, отечественные социологи утверждают, что «поведенческие стратегии в среде, изобилующей вызовами и угрозами, зависят от состояния и оценки собственного здоровья, качества жизни, целевой установки на здоровый образ жизни» [34, с. 114]. Данный подход правомерно указывает на то, что состояние здоровья как индивида, так и общества является фактором риска и фактором их безопасности.

Здоровье человека в современном философском дискурсе. В рамках современного философского осмысления вопросы здоровья человека рассматриваются в контексте проблематики биосоциальной природы человека, телесности человека, культуры здоро- 
вья, здоровья в системе мировоззренческих ценностей, здоровья и экологии и др.

Анализ здоровья с позиции дискурса о биологическом и социальном в человеке осуществляется в работах Д.Н. Давиденко, К.А. Оглоблина, Ю.А. Семенова и др. [13; 30; 38]. По мнению исследователей, здоровье человека представляет «качество приспособления организма к условиям внешней среды и... формируется в результате взаимодействия экзогенных (природных и социальных) и эндогенных (наследственность, конституция, пол, возраст) факторов» [13, с. 31], т.е. состояние здоровья человека зависит от биологических механизмов организма и социальных условий жизни людей. Именно совокупность этих факторов определяет потенциал здоровья человека, его нормальное функционирование в социуме. Подходя комплексно к проблеме, К.А. Оглоблин определяет здоровье как «нормальное психосоматическое состояние человека, отражающее его полное физическое, психическое и социальное благополучие и обеспечивающее полноценное выполнение трудовых, социальных и биологических функций» [30, с. 36].

Вопросы здоровья в аспекте философскоантропологического осмысления человеческой телесности рассматриваются в работах Р. Барта, Ж. Батая, Ж. Бодрийяра, М. МерлоПонти, М. Фуко и др. [5; 6; 9; 27;39]. Западные исследователи придают телесности человека особую значимость, считая, что именно она является интегральной характеристикой личности, определяющей его присутствие этом мире. В то же время понятие телесности для них не является тождественным биологической структуре, напротив, оно выходит за ее пределы и охватывает как физические, так и метафизические свойства человека.

Российские авторы М.3. Воробьев, Л.В. Жаров, В.Л. Круткин, Р.В. Маслов, В.А. Подорога видят в телесности человека основу для понимания им своей духовности $[10 ; 18 ; 22 ; 24 ; 33]$. Согласно позиции авторов, здоровье выступает фактом существования человека как телесного существа, которое понимает, что этим его природа не исчерпывается и есть иные, не телесные, структуры, определяющие его жизнедеятельность.

В рамках философского осмысления здоровья человека имеет место аксиологичес- кий подход, рассматривающий здоровье как ценность, обусловленную культурой общества и его мировоззренческими установками. В этом аспекте здоровье человека исследуется в работах Е.В. Андриенко, Р.А. Пидлубного, С.А. Нижникова, Б.Г. Юдина и др. [3; $29 ; 44]$. По мнению авторов, ценность здоровья определяется теми идеалами, нормами и принципами, которые доминируют в культуре общества. Как отмечают исследователи, «в каждую историческую эпоху культура вырабатывает определенные представления о том, в чем именно заключаются здоровье и болезнь, каковы пути сохранения или обретения здоровья, и всякий раз эти представления самым тесным образом связаны с пониманием мира, человека и взаимоотношений между ними» [44, с. 33]. Рассматривая здоровье сквозь призму системы ценностей, господствующей в общества, а также их переоценку, определяющую кризисные явления в социуме, исследователи утверждают, что именно мировоззренческие установки закладывают в сознание индивида представления о норме и патологии в функционировании человеческого организма.

Осмысление здоровья человека осуществляется и в русле экософской парадигмы, которая рассматривает человека как биосферное явление, подвергающееся уничтожению в условиях замещения естественной среды на искусственную, вытеснения биосферы техносферой. Данный подход к здоровью человека берет начало в работах Н.Н. Моисеева, Э.С. Демиденко, В.А. Кутырева и др. [28; $14 ; 23]$. Исследователи справедливо отмечают, что социоприродная эволюция на Земле приобретает взрывной характер благодаря неконтролируемой и вооруженной техникой человеческой сверхдеятельности ради социально спровоцированного удовлетворения избыточных человеческих потребностей.

Рассматривая угрозы здоровью человека со стороны техногенной цивилизации, ученые призывают к восстановлению биосферы как необходимой природной составляющей жизни человека. Для этого необходимо формирование нового мировоззрения, способствующего сохранению человека как биологического и социального существа.

В философском дискурсе сложился экзистенциальный подход к здоровью, в рамках ко- 
торого здоровье человека рассматривается как «отражение его парадоксального стремления продлить конечность своего существования» [20, с. 71]. Философия экзистенциализма акцентирует внимание на смысложизненных проблемах человеческого бытия, которые связаны с вопросами о конечности этого бытия, границах свободы личности, индивидуальном выборе и ответственности, значимости пограничных ситуаций и т.п. В пространстве этой проблематики жизнь человека рассматривается как движение от рождения к смерти, а здоровье является лишь «со-бытием» в этом процессе [40]. Причем это «со-бытие» непосредственно связано с проблемой выбора человеком конструктивного или деструктивного отношения к своему здоровью.

Заключение. В целом следует отметить, что проблема здоровья - это не сугубо медицинский вопрос, это проблема онтологическая, открывающая возможность понять существование человека как целостности, в совокупности его биосоциальной природы и духовной сущности. Только такой холисткий подход позволяет осуществить комплексное исследование здоровья человека в условиях смены культурных моделей.

Вышеизложенные подходы к проблеме здоровья человека представляются вполне концептуальными для философско-антропологического исследования проблемы здоровья человека в контексте трансформации культурных парадигм и появлении новых вызовов. Философско-антропологический анализ предполагает интеграцию подходов к здоровью человека, сложившихся в социально-гуманитарном знании, поскольку это дает возможность осуществить комплексное исследование проблемы здоровья человека в условиях развития цифровой культуры в современном обществе.

\section{Список источников}

1. Акчурин Б.Г. Телесность как проявление человеческого потенциала // Социальногуманитарные знания. 2004. №2. С. 31-37.

2. Амосов Н.М. Мое мировоззрение // Вопросы философии. 1992. №6. С. 50-74.

3. Андриенко Е. В. Пидлубный Р. А. Здоровье как глобальная ценность // Современ- ные социальные процессы в контексте глобализации. Краснодар: КубГУ, 2019. С. 108-114.

4. Антонова Н.Л. Социология здоровья как перспективная отрасль социологической науки // Образование и наука. 2004. №3(27). C. $112-119$.

5. Барт Р. Удовольствие от текста // Семиотика. Поэтика. М.: Прогресс, 1989. 616 с.

6. Батай Ж. Внутренний опыт. СПб.: Аксиома: Мифрил, 1997. 336 с.

7. Безуглая Т.И. Психологическое здоровье как психолого-педагогическая проблема// Евразийский Союз Ученых (ЕСУ). 2020. №3(72). С. 4-9.

8. Бехтерев В.М. Объективная психология. М.: Наука. Серия «Памятники психологической мысли», 1991. 480 с.

9. Бодрийяр Ж. Символический обмен и смерть. М.: Добросвет, 2000. 389 с.

10. Воробьев М.3. Психосоматика в культуре личности и социума (теоретическое обоснование роли и места) // Телесность человека: междисциплинарные исследования. М.: Таврида - Симферополь, 1993. С. 3-7.

11. Горяинова Н.С. Здоровье студенческой молодежи и национальная безопасность России // Национальное здоровье. 2015. №1. C. 72-79.

12. Гутик Т.В. Социологический подход к изучению здоровью населения // Ученые записки ТОГУ. 2017. Т. 8. №4. С. 209-216.

13. Давиденко Д.Н. Здоровье как биосоциальный потенциал жизнедеятельности человека // Здоровье - основа человеческого потенциала: проблемы и пути их решения. 2006. T. 1. №1. С. 30-33.

14. Демиденко Э. С. Экотехнологический Апокалипсис, или «конец света» природного человека. Брянск: Изд-во «Очаг», 1993. C. 184-204.

15. Дмитриева Е. В. От социологии медицины к социологии здоровья // Социологические исследования. 2003. №11. С. 90-97.

16. Дубровина И.В. Психологическое здоровье детей и подростков в контексте психологической службы. Екатеринбург: Деловая книга, 2000. 176 с.

17. Егорова Е. О. Капитал здоровья как компонента человеческого капитала // Экономика России в XXI веке: материалы XII Всероссийской научно-практической конференции. В 2-х томах. Томский политехничес- 
кий университет. Т. 1. Томск: Изд-во НИТПУ, 2015. С. 387-392.

18. Жаров Л.В. Человеческая телесность: философский анализ. Ростов-на-Дону: Издво Рост. ун-та, 1988. 126 с.

19. Завгородняя О.В. Психологическое здоровье человека: теоретические и прикладные аспекты: монография. Киев: Информационно-аналитическое агентство, 2008. 169 с.

20. Исмаилов А. Ю. Философско-антропологический концепт «человек здоровый»: постановка проблемы // Вестник Челябинской государственной академии культуры и искусства. 2015. №2(42). С. 71-75.

21. Казиева М.3. Здоровье молодежи в контексте обеспечения национальной безопасности российского общества // Гуманитарные, социально-экономические и общественные науки. 2016. №12. С. 53-56.

22. Круткин В.Л. Телесность человека в онтологическом измерении // Общественные науки и современность. 1997. №4. C. 147-151.

23. Кутырев В.А. Естественное и искусственное; борьба миров. Н. Новгород: Изд-во «Нижний Новгород», 1994. 199 с.

24. Маслов Р. В. Философия телесности человека // Вестник СПбГУ. 2004. №9. C. $78-81$.

25. Маслоу А. Дальние пределы человеческой психики. СПб: Евразия, 1997. 432 с.

26. Маслоу А. Мотивация и личность. СПб.: Питер, 2008. 352 с.

27. Мерло-Понти М. Феноменология восприятия. СПб.: Ювента, Наука, 1999.

28. Моисеев Н.Н. С мыслями о будущем России. М.: Фонд содействия развитию социальных и политических наук, 1997. 210 с.

29. Нижников С.А. Пути обретения здоровья и мировоззрение // Философия здоровья. М.: РАН, 2001. С. 5-24.

30. Оглоблин К.А. Здоровье как философско-мировоззренческий феномен // Человек и образование. 2009. №3(20). С. 76-80.

31. Олпорт Г. Личность в психологии. М.: КСП+; Ювента, 1998. 345 с.

32. Паутов И.С. Современные теоретические подходы к осмыслению здоровья как социального феномена: концепция человеческих возможностей и социология риска// Петербургская социология сегодня. 2014. T. 1. №1-1(5). C. 289-307.
33. Подорога В.А. Феноменология тела. Введение в философскую антропологию. М.: Ad Marginem, 1995. $341 \mathrm{c}$.

34. Поздеева Е.Г., Евсеев В.В. Здоровье и безопасность как взаимоусилители в обществе риска: социологический аспект // Здоровье - основа человеческого капитала: проблемы и пути из решения. 2018. Т. 13. №8. C. $108-115$.

35. Решетников М.М. Психическое здоровье населения - современные тенденции и старые проблемы // Национальный психологический журнал. 2015. №1(17). С. 9-15.

36. Роджерс К.Р. Взгляд на психотерапию. Становление человека. М.: Издательская группа «Прогресс», «Универс», 1994. $478 \mathrm{c}$.

37. Розин В.М. Здоровье как философская и социально-психологическая проблема // Мир психологии: научно-методический журнал. 2000. №1. С. 12-30.

38. Семенова Ю. А Человек на пути к телесному совершенству с позиции философии здоровья // Sciences of Europe. 2016. №4. С. 81-84.

39. Фуко М. Рождение клиники. М.: Смысл, $1998.310 \mathrm{c.}$

40. Хайдеггер М. Что зовется мышлением? М.: Академический проект, 2007. 320 с.

41. Чубенко Д.С. Социология здоровья: становление и пути развития // Вестник Нижегородского университета им. Н.И. Лобачевского. 2007. №1(6). С. 118-122.

42. Шувалов А.В. Антропологические аспекты психологии здоровья // Национальный психологический журнал. 2015. №4(20). C. 23-36.

43. Шушунова Т.Н. Категория здоровья в истории развития социогуманитарного знания // Журнал Белорусского государственного университета. Экология. 2017. №4. С. 11-16.

44. Юдин Б.Г., Степанова Г.Б. Здоровье человека: факт, норма, ценность. М.: Изд-во МГУ, 2009. $188 \mathrm{c.}$

\section{References}

1. Akchurin B.G. Telesnost' kak projavlenie chelovecheskogo potenciala [Physicality as a manifestation of human potential]. Social'nogumanitarnye znanija [Socio-humanitarian knowledge]. 2004; (2): 31-37. (In Russ.). 
2. Amosov N.M. Moe mirovozzrenie [My worldview]. Voprosy filosofii [Questions of Philosophy]. 1992; (6): 50-74. (In Russ.).

3. Andrienko E.V. Pidlubnyj R.A. Zdorov'e kak global'naja cennost' [Health as a global value]. Sovremennye social'nye processy v kontekste globalizacii [Modern social processes in the context of globalization]. Krasnodar: KubGU, 2019. P. 108-114. (In Russ.).

4. Antonova N.L. Sociologija zdorov'ja kak perspektivnaja otrasl' sociologicheskoj nauki [Sociology of health as a promising branch of sociological science]. Obrazovanie i nauka [Education and Science]. 2004; 3(27): 112-119. (In Russ.).

5. Bart R. Udovol'stvie ot teksta [The pleasure of the text]. Semiotika. Pojetika [Semiotics. Poetics]. Moscow: Progress, 1989. 616 p. (In Russ.).

6. Bataj Zh. Vnutrennij opyt [Internal experience]. Saint Petersburg: Aksioma: Mifril, 1997. 336 p. (In Russ.).

7. Bezuglaja T. I. Psihologicheskoe zdorov'e kak psihologo-pedagogicheskaja problema [Psychological health as a psychological and pedagogical problem]. Evrazijskij Sojuz Uchenyh (ESU) [Eurasian Union of Scientists (ESU)]. 2020; 3(72): 4-9. (In Russ.).

8. Behterev V.M. Ob'ektivnaja psihologija [Objective psychology]. Moscow: Nauka. Serija «Pamjatniki psihologicheskoj mysli», 1991. 480 p. (In Russ.).

9. Bodrijjar Zh. Simvolicheskij obmen i smert' [Symbolic exchange and death]. Moscow: Dobrosvet, 2000. 389 p. (In Russ.).

10. Vorob'ev M.Z. Psihosomatika v kul'ture lichnosti i sociuma (teoreticheskoe obosnovanie roli i mesta) [Psychosomatics in the culture of personality and society (theoretical justification of the role and place)]. Telesnost' cheloveka: mezhdisciplinarnye issledovanija [Human physicality: interdisciplinary research]. Moscow: Tavrida - Simferopol', 1993. P. 3-7. (In Russ.).

11. Gorjainova N. S. Zdorov'e studencheskoj molodezhi i nacional'naja bezopasnost' Rossii [Health of student youth and national security of Russia]. Nacional'noe zdorov'e [National health]. 2015; (1): 72-79. (In Russ.).

12. Gutik T.V. Sociologicheskij podhod $\mathrm{k}$ izucheniju zdorov'ju naselenija [A sociological approach to the study of population health].
Uchenye zapiski TOGU [Scientific notes of TOGU]. 2017; 8(4): 209-216. (In Russ.).

13. Davidenko D.N. Zdorov'e kak biosocial'nyj potencial zhiznedejatel'nosti cheloveka [Health as a biosocial potential of human activity].Zdorov'e - osnova chelovecheskogo potenciala: problemy i puti ih reshenija [Health - the basis of human potential: problems and ways to solve them]. 2006; 1(1): 30-33. (In Russ.).

14. Demidenko Je. S. Jekotehnologicheskij Apokalipsis, ili «konec sveta» prirodnogo cheloveka [Ecotechnological Apocalypse, or the «end of the world» of natural man]. Brjansk: Izdvo «Ochag», 1993. P. 184-204. (In Russ.).

15. Dmitrieva E.V. Ot sociologii mediciny $\mathrm{k}$ sociologii zdorov'ja [From the sociology of medicine to the sociology of health]. Sociologicheskie issledovanija [Sociological research]. 2003; (11): 90-97. (In Russ.).

16. Dubrovina I. V. Psihologicheskoe zdorov'e detej i podrostkov v kontekste psihologicheskoj sluzhby [Psychological health of children and adolescents in the context of psychological service]. Ekaterinburg: Delovaja kniga, 2000. 176 p. (In Russ.).

17. Egorova E.O. Kapital zdorov'ja kak komponenta chelovecheskogo kapitala [Health capital as a component of human capital]. Jekonomika Rossii v XXI veke: materialy XII Vserossijskoj nauchno-prakticheskoj konferencii. V 2-h tomah. Tomskij politehnicheskij universitet. T. 1 [The economy of Russia in the XXI century: materials of the XII All-Russian Scientific and Practical Conference. In 2 volumes. Tomsk Polytechnic University. Vol. 1]. Tomsk: Izd-vo NITPU, 2015. P. 387-392. (In Russ.).

18. Zharov L.V. Chelovecheskaja telesnost': filosofskij analiz [Human physicality: philosophical analysis]. Rostov-on-Don: Izd-vo Rost. un-ta, 1988. 126 p. (In Russ.).

19. Zavgorodnjaja O.V. Psihologicheskoe zdorov'e cheloveka: teoreticheskie i prikladnye aspekty: monografija [Psychological human health: theoretical and applied aspects: monograph]. Kiev: Informacionno-analiticheskoe agentstvo, 2008. 169 p. (In Russ.).

20. Ismailov A. Ju. Filosofsko-antropologicheskij koncept «chelovek zdorovyj»: postanovka problemy [Philosophical and anthropological concept of «healthy person»: problem statement]. Vestnik Cheljabinskoj gosudarstvennoj akademii kul'tury $i$ iskusstva [Bulletin of the 
Chelyabinsk State Academy of Culture and Art]. 2015; 2(42): 71-75. (In Russ.).

21. Kazieva M.Z. Zdorov'e molodezhi v kontekste obespechenija nacional'noj bezopasnosti rossijskogo obshhestva [Youth health in the context of ensuring national security of the Russian society]. Gumanitarnye, social'no-jekonomicheskie i obshhestvennye nauki [Humanities, socio-economic and social sciences]. 2016; (12): 53-56. (In Russ.).

22. Krutkin V.L. Telesnost' cheloveka v ontologicheskom izmerenii [Human physicality in the ontological dimension]. Obshhestvennye nauki i sovremennost' [Social Sciences and modernity]. 1997; (4): 147-151. (In Russ.).

23. Kutyrev V.A. Estestvennoe i iskusstvennoe; bor'ba mirov [Natural and artificial; the struggle of the worlds]. N. Novgorod: Izd-vo «Nizhnij Novgorod», 1994. 199 p. (In Russ.).

24. Maslov R.V. Filosofija telesnosti cheloveka [Philosophy of human physicality]. Vestnik SPbGU [Bulletin of St. Petersburg State University]. 2004; (9): 78-81. (In Russ.).

25. Maslou A. Dal'nie predely chelovecheskoj psihiki [The far limits of the human psyche]. Saint Petersburg: Evrazija, 1997. 432 p. (In Russ.).

26. Maslou A. Motivacija i lichnost' [Motivation and personality]. Saint Petersburg: Piter, 2008. 352 p. (In Russ.).

27. Merlo-Ponti M. Fenomenologija vosprijatija [Phenomenology of perception]. Saint Petersburg: Juventa, Nauka, 1999. (In Russ.).

28. Moiseev N.N. S mysljami o budushhem Rossii [With thoughts about the future of Russia]. Moscow: Fond sodejstvija razvitiju social'nyh i politicheskih nauk, 1997. 210 p. (In Russ.).

29. Nizhnikov S.A. Puti obretenija zdorov'ja i mirovozzrenie [Ways of gaining health and worldview]. Filosofija zdorov'ja [Philosophy of health]. Moscow: RAN, 2001. P. 5-24. (In Russ.).

30. Ogloblin K.A. Zdorov'e kak filosofsko-mirovozzrencheskij fenomen [Health as a philosophical and ideological phenomenon]. Chelovek $i$ obrazovanie [Man and education]. 2009; 3(20): 76-80. (In Russ.).

31. Olport G. Lichnost' v psihologii [Personality in psychology]. Moscow: KSP+; Juventa, 1998. 345 p. (In Russ.).

32. Pautov I.S. Sovremennye teoreticheskie podhody k osmysleniju zdorov'ja kak social'nogo fenomena: koncepcija chelovecheskih vozmozhnostej i sociologija riska [Modern theoretical approaches to understanding health as a social phenomenon: the concept of human capabilities and the sociology of risk]. Peterburgskaja sociologija segodnja [St. Petersburg Sociology today]. 2014; 1(1-1(5)): 289-307. (In Russ.).

33. Podoroga V.A. Fenomenologija tela. Vvedenie v filosofskuju antropologiju [Phenomenology of the body. Introduction to philosophical anthropology]. Moscow: Ad Marginem, 1995. 341 p. (In Russ.).

34. Pozdeeva E.G., Evseev V.V. Zdorov'e i bezopasnost' kak vzaimousiliteli v obshhestve riska: sociologicheskij aspekt [Health and safety as mutual reinforcers in a risk society: a sociological aspect]. Zdorov'e - osnova chelovecheskogo kapitala: problemy i puti iz reshenija [Health - the basis of human capital: problems and solutions]. 2018; 13(8): 108-115. (In Russ.).

35. Reshetnikov M.M. Psihicheskoe zdorov'e naselenija - sovremennye tendencii i starye problemy [Mental health of the population modern trends and old problems]. Nacional'nyj psihologicheskij zhurnal [National Psychological Journal]. 2015; 1(17): 9-15. (In Russ.).

36. Rodzhers K. R. Vzgljad na psihoterapiju. Stanovlenie cheloveka [A look at psychotherapy. The formation of man]. Moscow: Izdatel'skaja gruppa «Progress», «Univers», 1994. 478 p. (In Russ.).

37. Rozin V.M. Zdorov'e kak filosofskaja i social'no-psihologicheskaja problema [Health as a philosophical and socio-psychological problem]. Mir psihologii: nauchno-metodicheskij zhurnal The world of psychology: a scientific and methodological journal]. 2000; (1): 12-30. (In Russ.).

38. Semenova Ju. A Chelovek na puti k telesnomu sovershenstvu s pozicii filosofii zdorov'ja [Person on the way to bodily perfection from the standpoint of the philosophy of health]. Sciences of Europe. 2016; (4): 81-84. (In Russ.).

39. Fuko M. Rozhdenie kliniki [The birth of the clinic]. Moscow: Smysl, 1998. 310 p. (In Russ.).

40. Hajdegger M. Chto zovetsja myshleniem? [What is called thinking?]. Moscow: Akademicheskij proekt, 2007. 320 p. (In Russ.).

41. Chubenko D.S. Sociologija zdorov'ja: stanovlenie i puti razvitija [Sociology of health: 
formation and ways of development]. Vestnik Nizhegorodskogo universiteta im. N.I. Lobachevskogo [Bulletin of the Nizhny Novgorod University named after N. I. Lobachevsky]. 2007; 1(6): 118-122. (In Russ.).

42. Shuvalov A. V. Antropologicheskie aspekty psihologii zdorov'ja [Anthropological aspects of health psychology]. Nacional'nyj psihologicheskij zhurnal [National Psychological Journal]. 2015; 4(20): 23-36. (In Russ.).
43. Shushunova T.N. Kategorija zdorov'ja v istorii razvitija sociogumanitarnogo znanija [Category of health in the history of the development of socio-humanitarian knowledge]. Zhurnal Belorusskogo gosudarstvennogo universiteta. Jekologija [Journal of the Belarusian State University. Ecology]. 2017; (4): 11-16. (In Russ.).

44. Judin B. G., Stepanova G.B. Zdorov'e cheloveka: fakt, norma, cennost' [Human health: fact, norm, value]. Moscow: Izd-vo MGU, 2009. 188 p. (In Russ.).

Статья поступила в редакиию 21.12.2021; одобрена после рецензирования 23.12.2021; принята к публикаџии 25.12.2021.

The article was submitted on 21.12.2021; approved after reviewing on 23.12.2021; accepted for publication on 25.12.2021.

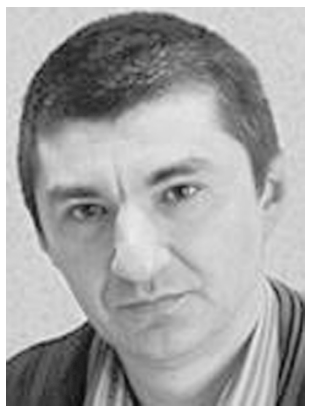

\section{ИНФОРМАЦИЯ ОБ АВТОРАХ}

Чернов Илья Владимирович - доцент, заведующий кафедрой физического воспитания, Новочеркасский инженерномелиоративный институт имени А. К. Кортунова (филиал), Донской государственный аграрный университет.

Россия, г. Новочеркасск, ул. Пушкинская, 111

Ilya V. Chernov - Associate Professor, Head of the Department of Physical Education, Novocherkassk Reclamation Engineering Institute named after A.K. Kortunov (branch), Donskoy State Agrarian University.

111 Pushkinskaya st., Novocherkassk, Russia 